\title{
THERMOPHILIC XYLANASE PRODUCTION ROM ISOLATES OF MACULA' HOT SPRINGS BACTERIA USING CORN COBS WASTE MEDIA
}

\author{
Lupita Denta Putri ${ }^{1,2 *}$, Hasna Natsir ${ }^{1,2}$, Seniwati Dali ${ }^{1,2}$ \\ ${ }^{1}$ Biochemistry Laboratory, Department of Chemistry, Faculty of Mathematics and Natural Sciences, \\ Hasanuddin University \\ ${ }^{2}$ Department of Chemistry, Faculty of Mathematics and Natural Sciences, Hasanuddin University, \\ Perintis Kemerdekaan Street KM 10, Tamalanrea Makasssar, Indonesia 90245 \\ *Corresponding author: Lupitadenta27@gmail.com
}

\begin{abstract}
Abstrak. Xilanase merupakan enzim ekstraseluler yang memiliki prospek sebagai enzim penghidrolisis hemiselulosa (xilan). Dalam penelitian ini, dilakukan isolasi bakteri dari sumber air panas Makula', Tana Toraja serta menentukan kondisi optimum dalam memproduksi enzim xilanase. Adapun tahapan yang dilakukan yaitu peremajaan bakteri, pembuatan medium inokulum dan medium produksi, pengukuran OD (Optical Density), pengukuran kadar protein dan pengujian aktivitas xilanase. Hasil yang diperoleh menunjukkan bahwa waktu produksi untuk B. stearothermophilus SL3A adalah pada jam ke-48 dengan nilai aktivitas $0,1237 \mathrm{mU} / \mathrm{mL}$ dan $B$. stearothermophilus SL3S pada jam ke-60 dengan nilai aktivitas $0,1593 \mathrm{mU} / \mathrm{mL}$. $B$. stearothermophilus SL3A memiliki kadar protein $9,59 \mathrm{mg} / \mathrm{mL}$ dan untuk B. stearothermophilus SL3S memiliki kadar protein $10,07 \mathrm{mg} / \mathrm{mL}$. Karakteristik xilanase dari bakteri $B$. stearothermophilus SL3A dan B. stearothermophilus SL3S bekerja optimum pada pH 7 suhu 45 ${ }^{\circ} \mathrm{C}$. Ekstrak kasar enzim xilanase hasil isolasi dapat menghidrolisis substrat xilan dari tongkol jagung. Penambahan logam $\mathrm{CaCl}_{2}, \mathrm{MgCl}_{2}, \mathrm{NiCl}_{2}$ dapat meningkatkan aktivitas enzim xilanase dan $\mathrm{CoCl}_{2}$ menurunkan aktivitas enzim sehingga bersifat inhibitor.
\end{abstract}

Kata kunci: Bacillus stearothermophilus, xilan, xilanase

Abstract. Xylanases is an extracellular enzyme that has prospects as enzymes that hydrolyze hemicellulose (xylan). In this study, carried out isolatied of bacteria from the hot springs Makula', Tana Toraja and determine the optimum conditions in producing the xylanase enzyme. The steps being taken are the rejuvenation of bacteria, the manufacture medium inoculum and the production medium, the measurement OD (Optical Density) measurements of protein and testing activities xylanase. The results obtained showed that the production time for $B$. stearothermophilus SL3A is in the 48 hours with a value of 0.1237 activity $\mathrm{mU} / \mathrm{mL}$ and $B$. stearothermophilus SL3S at the 60 hours with a value of 0.1593 activity $\mathrm{mU} / \mathrm{mL}$. $B$. stearothermophilus SL3A have a protein content of $9.828 \mathrm{mg} / \mathrm{mL}$ and for B. stearothermophilus SL3S have a protein content of $10.07 \mathrm{mg} / \mathrm{mL}$. Characteristics bacterial xylanase from $B$. stearothermophilus SL3A and B. stearothermophilus SL3S work optimally at $\mathrm{pH} 7$ a temperature of $45{ }^{\circ} \mathrm{C}$. Crude extract of the isolated xylanase enzyme can hydrolyze substrate is xylan corn cobs. The addition of metal $\mathrm{CaCl}_{2}, \mathrm{MgCl}_{2}, \mathrm{CaCl}_{2}$ can increase the activities of the enzyme xylanase and $\mathrm{CoCl}_{2}$ decreases the activities of enzymes that are inhibitors.

Keywords : Bacillus stearothermophilus, xylan, xylanases 


\section{INTRODUCTION}

Technological developments in various fields make it very easy to do various things and provide many benefits. One technology in the field of science is biotechnology that studies the use of living things (bacteria, fungi and viruses), as well as products from living things (enzymes and alcohol) in the production process to produce goods and services. Biotechnology in the modern era produces many products on an industrial scale (Amien, 2012). Enzymes play an important role in the industry including $\alpha$-amylase, proteases, and xylanase.

Xylanase is one of the enzymes needed by industry, namely the paper industry as paper bleach and lignocellulose bioconversion for fuel. Xylanase is a hydrolase enzyme that has the ability to hydrolyze xylan (hemicellulose) to $\mathrm{xyl}$ oligosaccharides and xylose. The use of xylanase in the pulp pre-bleaching process can reduce the amount of chlorine compounds used (Susilowati et al., 2012).

Xylanase can be produced by microbes through a fermentation process, which is usually produced by bacteria or yeast (Richana et al., 2008).

One of the xylanase producing bacteria is thermophilic bacteria. Thermophilic bacteria are bacteria that can grow at high temperatures between 45$55^{\circ} \mathrm{C}$ (Patong, 2013). Thermophilic bacteria originating from hot springs and volcanic craters (geothermal regions) have the potential to produce thermostable enzymes, because the ability of enzymes to work at high temperatures is influenced by the environmental conditions in which the bacteria grow (Susilowati et al., 2012).
Indonesia, especially South Sulawesi, has hot springs that are a medium for the growth of thermophilic microorganisms. Makula's hot springs, Tana Toraja district is one of the geothermal sources which is the location for sampling the xylanase-producing thermophilic bacteria. Several studies have managed to isolate and characterize thermophilic bacteria producing xylanase enzymes, including bacterial isolates $\mathrm{M}$ 13.2A as long as Manado seawater has optimum activity at $\mathrm{pH} 8$ and temperatures of $70^{\circ} \mathrm{C}$ (Fawzya et al., 2013) and bacterial isolates IIA-3 isolated from Sonai hot springs, Southeast Sulawesi have the potential to be xylanolytic at temperatures of $50^{\circ} \mathrm{C}$ and $\mathrm{pH} 9$ (Susilowati et al., 2012).

The production of xylanase enzymes by microorganisms requires a substrate as an induction ie xylan. The use of pure xylan on an industrial scale is too expensive, so agricultural waste that has a major component of lignocellulose is expected to be used as a carbon source (Trismilah and Waltam, 2009). One of the goals in the development of biotechnology is to pioneer the use of microorganisms in bioconversion of waste. By using the services of microorganisms, the use of berlignocelulose waste can produce extracellular enzymes that are able to degrade berlignocellulose materials into their constituent fractions (Richana, 2002).

According to Fachry (2013), lignocellulose waste is agricultural waste containing hemicellulose, cellulose and lignin. One of the agricultural wastes containing lignocellulose and its abundant availability in nature is corn cobs. Given that corn production in Indonesia is a largescale production, it will easily get corn 
cobs waste, especially in rural areas (Richana et al., 2007).

The results of the study by Setyawati (2006), showed that agricultural waste such as corn cobs had a hemicellulose content of $40 \%$ which is a xylanase substrate used as a carbon source. Corncob is the highest lignocellulosic material containing xylan at $12.4 \%$ compared to other agricultural wastes (Richana, 2004 in Salupi, 2011). Thus in this study the isolation of thermofilic microbial sources of Makula 'hot springs, Tana Toraja to produce xylanase enzymes using corncob waste as its substrate.

\section{MATERIAL AND METHODS Materials}

The materials used in this study were corn cobs, pure xylan, water and sediment samples from Makula's hot springs, Tana Toraja, peptone, yeast extract, $\mathrm{NaCl}$, $\mathrm{MgSO}_{4} .7 \mathrm{H}_{2} \mathrm{O}, \quad \mathrm{K}_{2} \mathrm{HPO}_{4}, \quad \mathrm{NaOH}$, bakto agar, $70 \%$ alcohol, spirits, aluminum foil, DNS reagents, buffer citrate and phosphate buffer and universal $\mathrm{pH}$ paper.

\section{Tools}

The tools used in this study are basin, flower pot, analyzer, oven, desiccator, hot plate, petri dish, mortar, horn spoon, artificial waste making equipment, glassware, and Atomic Absorption Spectrophotometer (AAS), Back Scientific 205 VGP model.

\section{Procedures}

\section{Sampling}

Water samples in Makula's hot springs, Tana Toraja were taken as much as
$100 \mathrm{~mL}$ and $4 \mathrm{~g}$ of sediment samples were taken. Before the water and sediment samples are taken, measurements of the physical and chemical parameters are carried out at the location. The parameters measured are the temperature and $\mathrm{pH}$ of the sample. The sample is then put into a brown sterile bottle and then put in a cool box that is given ice and taken to the laboratory for further analysis.

\section{Isolation and Purification of Xylanase Producing Bacteria}

Water and sediment samples were each included in the enrichment medium (yeast extract $0.5 \%, 1 \% \mathrm{NaCl}, 1 \%$ peptone) in a ratio of 1: 2 then shake for 24 hours using a shaker. After that spread over the surface of the solid media as much as 200 $\mu \mathrm{L}$ and flatten it using an L-shaped stirring rod, then incubate at $40{ }^{\circ} \mathrm{C}$ for several days. A well-grown isolate is purified by scraping the quadrant several times and then incubated again at $40{ }^{\circ} \mathrm{C}$. After pure isolates were obtained, the quadrant scratched on solid media selection of xylanase-producing bacteria (substrate media) and incubated for 2 days at $40{ }^{\circ} \mathrm{C}$. In selective solid media, it is known that isolates have the potential to produce xylanase by forming clear zones around the colonies. Then the selected bacteria were grown in solid media containing corn cobs as a substrate.

\section{Morphological Characterization of Xylanase Producing Bacteria}

The isolate of the purified xylanase producing bacteria on corn cobs substrate media was characterized by its morphology 
by making several observations on the morphology of the isolates. Observations carried out included microscopic, macroscopic, and simple biochemical tests.

\section{Determination of the Optimal Time for Xylanase Production}

The selected isolates were then inoculated on the inoculum medium containing corn cobs and then incubated at $40^{\circ} \mathrm{C}, \mathrm{pH} 7$, and the speed of the shaker waterbath $150 \mathrm{rpm}$ for 24 hours. $10 \%$ was inoculated into the production medium, then incubated in the waterbath shaker at $40^{\circ} \mathrm{C}, \mathrm{pH} 7$, and $150 \mathrm{rpm}$ for 5 days. Every 12 hours sampling is carried out for measurement of microbial growth known as the measurement of OD (Optical Density) at a wavelength of $600 \mathrm{~nm}$, measurement of xylanase enzyme activity and protein analysis (Nakamura et al., 1993).

\section{Testing of Xylanase Activity}

The xylanase enzyme activity was measured by detecting reducing sugars formed using DNS reagents. Enzyme activity was measured by mixing $1 \mathrm{~mL}$ enzyme, $1 \mathrm{~mL} 1 \%$ xylan substrate, phosphate buffer solution $\mathrm{pH} 7.0$ (made duplo) then incubated at $40^{\circ} \mathrm{C}$ for 60 minutes. Incubation was stopped with the addition of $3 \mathrm{~mL}$ of DNS reagent, then heated in boiling water for 30 minutes. Absorbance was measured at maximum wavelengths and standard xylose was used as a comparison (Nakamura et al., 1993 and Susilowati et al., 2012). The xylanse enzyme activity can be calculated using the formula:

Xylose level $(\mu g r / m L)$

Molecule weight of Xilosa (gr/mol) x Incubation time (menit)
One unit of xylanase activity $(\mathrm{U} / \mathrm{mL})$ is defined as the amount of enzyme that releases $\mu \mathrm{mol}$ xylose per minute.

\section{Measurement of Protein Levels in the} Lowry Method

The composition of the Lowry B reagent is $2 \% \mathrm{Na} 2 \mathrm{CO} 3$ in $0.1 \mathrm{~N} \mathrm{NaOH} ; 1 \%$ CuSO4; Sodium-potassium-tartrate (100: 1: 1) with Lowry A reagent is a solution of phosphotungstic-phospho-molybdic

(Foolin) acid: Aquades (1: 1). Protein levels were measured using a spectrophotometer at maximum wavelengths using BSA (Bovine Serum Albumin) as a standard (Lowry et al., 1951).

An xylanase enzyme of $1 \mathrm{~mL}$, a standard solution of $1 \mathrm{~mL}$, distilled water of $1 \mathrm{~mL}$ each put into a test tube, then added a Lowry B solution of $2.5 \mathrm{~mL}$, homogenized and then left for 10 minutes. Then added $0.25 \mathrm{~mL}$ of Lowry A and reincubated at $25^{\circ} \mathrm{C}$ for 30 minutes with occasional shaking, then the absorbance was measured at the maximum wavelength of BSA determined by a UV-Vis spectrometer.

\section{Characterization of Xylanase Enzymes (Susilowati et al., 2012 and Natsir et al., 2010) \\ 7.1 Determination of Optimum Temperature}

The temperature of the enzymes used are $35^{\circ} \mathrm{C}, 40^{\circ} \mathrm{C}, 45^{\circ} \mathrm{C}, 50^{\circ} \mathrm{C}$, and $55^{\circ} \mathrm{C} .1$ $\mathrm{mL}$ of enzyme, $1 \mathrm{~mL}$ of $1 \%$ xylan substrate and phosphate buffer to $\mathrm{pH} 7.0$ (made duplo) were mixed and incubated for 60 minutes at a temperature range of $35^{\circ} \mathrm{C}$, $40^{\circ} \mathrm{C}, 45^{\circ} \mathrm{C}, 50^{\circ} \mathrm{C}$, and $55^{\circ} \mathrm{C}$. Incubation was stopped with the addition of $3 \mathrm{~mL}$ of 
DNS reagent, then heated in boiling water for 30 minutes. Absorbance is measured at a wavelength of $450 \mathrm{~nm}$ and the standard xylose is used as a comparison. Optimum xylanase activity is obtained at a certain temperature.

\subsection{Determination of Optimum Enzyme pH}

Buffer solution is added as a buffer $\mathrm{pH}$. The citrate buffer solution is used for a $\mathrm{pH}$ range of 5 and $\mathrm{pH}$, then a phosphate buffer for $\mathrm{pH} 7$ and $\mathrm{pH} 8$. A total of $1 \mathrm{~mL}$ of enzyme, $1 \mathrm{~mL}$ of $1 \%$ xylan substrate varied at $\mathrm{pH} 5 ; 6 ; 7 ; 860$ minutes at the optimum temperature that has been obtained. Incubation was stopped with the addition of $3 \mathrm{~mL}$ of DNS reagent, then heated in boiling water for 30 minutes. Absorbance is measured at a wavelength of $450 \mathrm{~nm}$ and the standard xylose is used as a comparison. Optimal xylanase activity is obtained at a certain $\mathrm{pH}$.

\section{Determination of Optimum Substrate Concentration}

The variation of the substrate used is a concentration of $0.5 \% ; 0.75 \% ; 1 \% ; 1.25 \%$ and $1.5 \% .1 \mathrm{~mL}$ of enzyme, $1 \mathrm{~mL}$ of xylan substrate with a concentration of $0.5 \%$; $0.75 \% ; 1 \% ; 1.25 \% ; 1.5 \%$ and buffer until the optimum $\mathrm{pH}$ that has been obtained (made duplo) is mixed and incubated for 60 minutes at the optimum temperature range that has been obtained. Incubation was stopped with the addition of $3 \mathrm{~mL}$ of DNS reagent, then heated in boiling water for 30 minutes. Absorbance is measured at a wavelength of $450 \mathrm{~nm}$ and the standard xylose is used as a comparison. Optimum xylanase activity is obtained at a certain temperature.

\section{Effect of Metal Ions on Enzyme Activity}

The effect of metal ions on enzyme activity was tested to find out what types of metals act as activators or inhibitors, the metals used are $\mathrm{Mg}^{2+}, \mathrm{Ca}^{2+}, \mathrm{Co}^{2+}$, and $\mathrm{Ni}^{2+}$. A mixture of $1 \mathrm{~mL}$ of enzyme, $1 \mathrm{~mL}$ of optimum concentration substrate, and buffer to optimum $\mathrm{pH}$ was added $1 \mathrm{~mL}$ of $\mathrm{MgCl}_{2}$ solution; $\mathrm{CaCl}_{2} ; \mathrm{CoCl}_{2}$; and $\mathrm{NiCl}_{2}$. With a concentration of $1 \mathrm{mM}$ and $5 \mathrm{mM}$. Incubated for 60 minutes at the optimum temperature range obtained. Incubation was stopped with the addition of $3 \mathrm{~mL}$ of DNS reagent, then heated in boiling water for 30 minutes. Absorbance is measured at a wavelength of $450 \mathrm{~nm}$ and the standard xylose is used as a comparison. Optimum xylanase activity is obtained at a certain temperature.

\section{RESULTS AND DISCUSSION}

\section{Isolation of Xylanase-Producing} Thermophilic Bacteria from Makula Hot Springs'

Samples from each isolate that grew well, were purified by scraping the quadrant several times on supplement media incubated at various temperatures of $40^{\circ} \mathrm{C} ; 45^{\circ} \mathrm{C}$; and $50{ }^{\circ} \mathrm{C}$ with $\mathrm{pH}$ 7. The purification of bacteria on supplement media has different growth rates as shown in Table 1.

This is because some bacterial isolates are able to adapt and match the growing environment and some other isolates are less adaptable to their environment. After pure isolates were obtained, quadrant scratches were carried out on solid media selection of xylanaseproducing bacteria (substrate media) containing $0.5 \%$ pure xylan and incubated 
for 48 hours at $40^{\circ} \mathrm{C}$. The addition of xylan aims to select bacteria that can produce xylanase to hydrolyze xylan (Thoyib et al., 2007). In selective solid media it is known that isolates have the potential to produce xylanase with the formation of clear zones around the colonies as shown in Figure 1.

Table 1. Bacterial Growth Data Isolated from Makula' Hot Springs

\begin{tabular}{cccccc}
\hline \multirow{2}{*}{$\mathrm{T}$} & & \multicolumn{5}{c}{ Scratches } \\
\cline { 3 - 6 } & Isolate & \multicolumn{2}{c}{ Supplement media } & Pure xylan substrate medai \\
\cline { 3 - 6 } & & Day 1 & Day 2 & Day 1 & Day 2 \\
\hline $40{ }^{\circ} \mathrm{C}$ & SL1A & ++++ & ++++ & ++++ & ++++ \\
& SL1S & ++++ & ++++ & ++++ & ++++ \\
& SL2A & ++ & ++ & ++ & ++ \\
& SL3A & +++++ & +++++ & +++++ & +++++ \\
$45{ }^{\circ} \mathrm{C}$ & SL3S & +++++ & +++++ & +++++ & +++++ \\
& SL1A & ++ & ++ & + & + \\
& SL1S & ++ & ++ & + & + \\
& SL2A & + & + & - & - \\
& SL3A & +++ & +++ & +++ & +++ \\
& SL3S & +++ & +++ & +++ & +++ \\
$50{ }^{\circ} \mathrm{C}$ & SL1A & + & + & - & - \\
& SL1S & + & + & - & - \\
& SL2A & + & + & - & - \\
& SL3A & ++ & + & + & + \\
& SL3S & ++ & + & + & +
\end{tabular}

Information :

$\begin{array}{lll}- & \text { no colonies } & \text { Location 1 Water Samples (SL1A) } \\ + & \text { Little colony } & \text { Location 1 Sediment Sample (SL1S) } \\ ++ & \text { less colonies } & \text { Location 2 Water Samples (SL2A) } \\ +++ & \text { enough colonies } & \text { Location 3 Water Samples (SL3A) } \\ ++++ & \text { many colonies } & \text { Location 3 Sediment Samples (SL3S) } \\ +++++ & \text { very many colonies } & \end{array}$

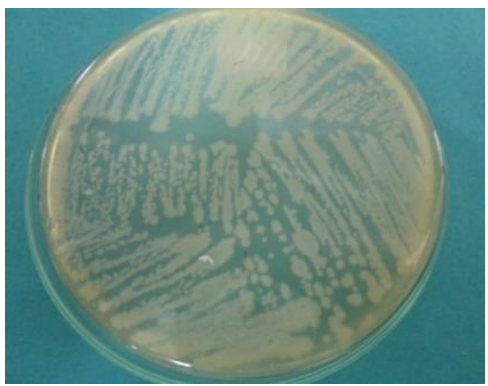

Figure 1. Isolate of Xylanase Producing Bacteria with Pure Xylan Substrate 
The most SL1A, SL1S, SL3A and SL3S bacteria were grown on pure xylan substrate media with an incubation temperature of $40^{\circ} \mathrm{C}$ so that the isolates were the selected isolates to be further investigated. This selected isolate was purified back into solid xylan-containing media from corn cobs as its substrate (Figure 3). Xylanolytic bacteria are bacteria that are able to utilize xylan as a carbon source that produces energy and generally produces extracellular xylanase.

Table 2. Bacterial Growth in Pure Xylan and Xylan Substrate Media from Corn Cob Scratches

\begin{tabular}{cccccc}
\multirow{2}{*}{$\mathrm{T}$} & Isolate & \multicolumn{2}{c}{ Supplement media } & \multicolumn{2}{c}{ Pure xylan substrate media } \\
\cline { 3 - 6 } & & Day 1 & Day 2 & Day 1 & Day 2 \\
\hline $40{ }^{\circ} \mathrm{C}$ & SL1A & +++ & +++ & +++ & ++++ \\
& SL1S & +++ & +++ & +++ & ++++ \\
& SL3A & ++++ & ++++ & ++++ & +++++ \\
& SL3S & ++++ & ++++ & ++++ & +++++
\end{tabular}

Information :

$$
\begin{array}{ll}
+++ & \text { enough colonies } \\
++++ & \text { many colonies } \\
+++++ & \text { very many colonies }
\end{array}
$$

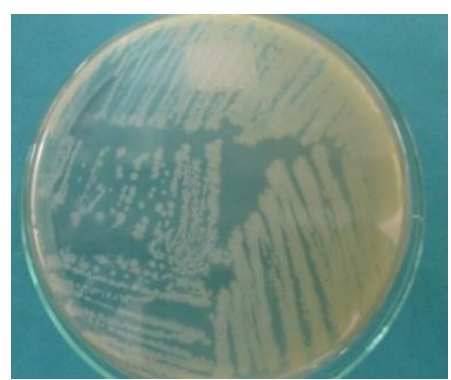

Figure 2. Bacterial Isolates in Media Containing Corn Cob and Incubated at $40^{\circ} \mathrm{C}$ with 48 hours

\section{Identification of Bacteria}

The purified bacterial isolates on substrate media containing corn cobs were then identified based on macroscopic, microscopic, and simple biochemical tests. Macroscopic observations of isolates have basil, chain or separate cells, some thick and thin. Microscopically shows isolates SL1A, SL1S, SL3A and SL3S including aerobic bacteria and including gram positive because after being given a purplish blue lugol solution. Simple biochemical tests consist of TSIA test (Triple Sugar Iron), SIM (Sulfide Indole Motility) test, MR-VP test (Methyl RedVoges Proskauer), Citrate test, Urea test and Carbohydrate test which includes Glucose test, Lactose test, test Sucrose, and Mannitol test. The results of biochemical tests on bacterial isolates SL1A, SL1S, SL3A and SL3S can be seen in Table 3. 
TSIA medium contains 3 types of sugar, namely glucose, lactose, and sucrose, there are also indicators of red phenol and $\mathrm{FeSO} 4$ to show $\mathrm{H} 2 \mathrm{~S}$ formation as indicated by the presence of black deposits. Test results on TSIA medium showed that bacteria SL1A, SL1S, SL3A, and SL3S were able to ferment glucose.

According to Lay (1994), if microorganisms can only ferment glucose, then the bottom (butt) of the media will be yellow (acidic) and the slant (media) will be red (alkaline). If microorganisms can ferment lactose or sucrose or both, then the slope and bottom of the media will be yellow (acidic) and the base of the media is sometimes broken down due to the formation of gases such as $\mathrm{H}_{2} \mathrm{O}$ and $\mathrm{CO}_{2}$. From the observations, the bacteria do not produce $\mathrm{H}_{2} \mathrm{~S}$ gas which is the result of anaerobic bacteria metabolism.

Medium SIM is used to determine whether or not there is movement of bacteria. The separation in order which is marked with black indicates that there is bacterial movement and it can be concluded that the bacteria immigrate from the inoculation line to the medium solid form of turbidity (Djide and Sartini, 2006). Test results with SIM medium showed negative results for indole, motile, and $\mathrm{H}_{2} \mathrm{~S}$ tests.

The MR test showed positive results that mixed acid fermentation occurred in the media but this bacterium was unable to use butanadiol fermentation through the VP test which was characterized by not changing the carbohydrate broth color to red. According to Djide and Sartini (2006), the MRVP test is used to determine the presence of mixed acid fermentation. Bacteria can ferment glucose and produce various products that are acidic so that it will reduce the $\mathrm{pH}$ of the lower growth media. This test is also carried out to produce acid through the hydrolysis process which produces simple organic acids.

Table 3. Biochemical Test Results of Bacterial Isolates

\begin{tabular}{|c|c|c|c|c|c|}
\hline \multirow{2}{*}{\multicolumn{2}{|c|}{ Testing }} & \multicolumn{4}{|c|}{ Result } \\
\hline & & SL1A & SL1S & SL3A & SL3S \\
\hline \multirow{4}{*}{ TSIA } & Slant & Alkali & Alkali & Alkali & Alkali \\
\hline & Butt & Acid & Acid & Acid & Acid \\
\hline & $\mathrm{H}_{2} \mathrm{~S}$ & - & - & - & - \\
\hline & Gas & - & - & - & - \\
\hline \multirow{3}{*}{ SIM } & Indol & - & - & - & - \\
\hline & Mot & - & - & - & - \\
\hline & $\mathrm{H}_{2} \mathrm{~S}$ & - & - & - & - \\
\hline \multirow{2}{*}{ MRVP } & MR & + & + & + & + \\
\hline & VP & - & - & - & - \\
\hline Uji Sitrat & & - & - & - & - \\
\hline Uji Urea & & - & - & - & - \\
\hline \multirow{4}{*}{ Uji Karbohidrat } & Glukosa & + & + & + & + \\
\hline & Laktosa & - & - & - & - \\
\hline & Sukrosa & - & - & - & - \\
\hline & Maltosa & - & - & - & - \\
\hline
\end{tabular}


Information :

Alkali : alkaline (red)

Acid : acidic (yellow)

$+\quad$ : shows positive results

: shows negative results
Citrate and urea tests showed negative results, bacterial isolates did not use citrate as a carbon source characterized by no change in color to blue. The bacterial isolate also does not produce urea which is characterized by the absence of ammonia which produces pink on the media.

One characteristic in identifying microorganisms is having the ability to ferment various carbohydrates and fermented products produced. The microbial properties, culture media used, and environmental factors such as $\mathrm{pH}$ and temperature determine the end result of carbohydrate fermentation. Glucose is the compound most often used by microorganisms in the fermentation process, besides that there are also media of sucrose and lactose (Djide and Sartini, 2006). Carbohydrate tests showed that the four bacteria were only able to ferment glucose while lactose, sucrose and maltose showed negative results.

According to the Berge's Manual of Determinative Bacteria, it is stated that based on the results of identification and biochemical tests on bacteria isolates SL1A, SL1S, SL3A, and SL3S are classified in the group of Bacillus stearothermophilus bacteria. Of the four isolates SL3A and SL3S isolates were selected and tested further because they had good growth.

According to research conducted by Richana (2008), isolates that are able to grow well provide an indication that these bacteria are able to utilize the only carbon source in growth media, namely xilan. Thus enzyme production will be better if using isolates that are able to grow well on the substrate induced with xylan. Testing of bacterial isolation carried out by Richana (2008) produced 25 colonies that were able to grow on xylan media and could produce clear zones, with a diameter of more than $3 \mathrm{~mm}$. Bacterial isolation carried out came from the land of tapioca waste disposal with acidic $\mathrm{pH}$ and calcareous soil with a $\mathrm{pH}$ of more than 7 . The results of measurement of xylanase activity in several test isolates showed the highest activity was achieved by RXA-III5 isolates of $11,182 \mathrm{U} / \mathrm{mL}$.

\section{Determination of the Optimum Time for Xylanase Enzyme Production}

Bacterial growth data shows that SL3A bacteria (Figure 3) and SL3S (Figure 4) undergo an adaptation phase, at the 0th to 12th hour. Bacteria begin to adjust to their new environment so that the cell has not yet split. During the initial condition, cells absorb nutrients and increase cell size. Although the population does not change because only changes in cell size, cell mass, and optical density begin to increase (Sopandi and Wardah, 2013).

Data on SL3A isolate fermentation time (Figure 3) and SL3S (Figure 4) at the 12th to 48th hours showed an exponential phase where in this phase bacterial cells were very actively dividing. This shows 
that all cells multiply because their nutritional needs are sufficient and cell metabolism is rapid (Sopandi and Wardah, 2013). The growth of SL3A bacteria (Figure 3) and SL3S (Figure 4) begins to slow down when it enters the stationary phase at the 48th hour to the 72nd hour. This is because nutrients and substrate in the media begin to decrease, some cells from the population die and some still do cell division so that the stability of life is maintained. The death phase occurs in the 84th SL3A and SL3S bacteria, this occurs because the amount of substrate and nutrients is almost exhausted so that the cells can no longer grow anymore

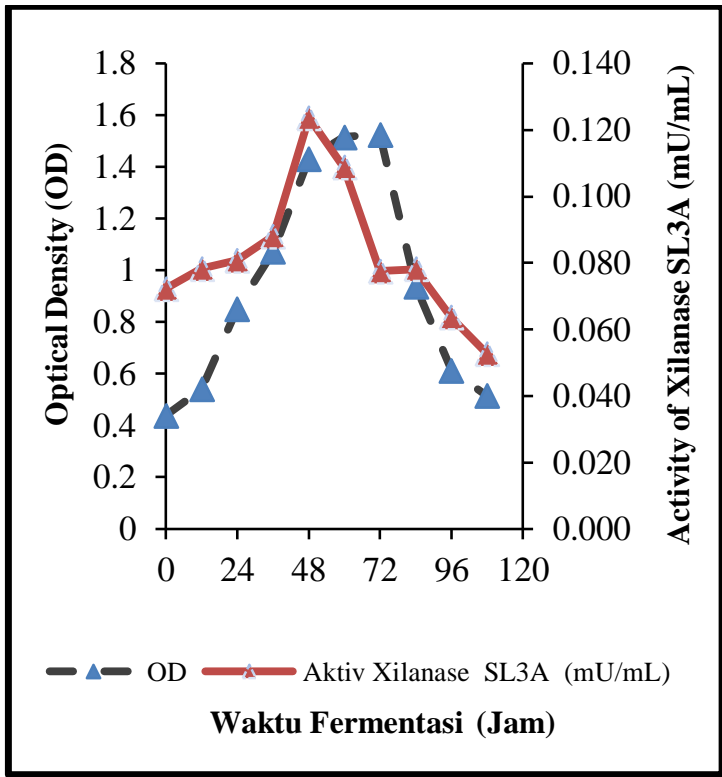

Figure 3. Xylanase Growth and Activity Curve of Bacteria B. stearothermophilus SL3A during Production time at conditions of $40^{\circ} \mathrm{C}$, [corn cob xilan] $0.5 \%$ and speed of 150 rpm

Testing of crude xylanase extract activity was carried out using $1 \%$ xylan as a substrate, phosphate buffer $\mathrm{pH} 7$, and incubation temperature of $40^{\circ} \mathrm{C}$ for 1 hour. The results showed that the optimum production time of xylanase from $B$. stearothermophilus SL3A isolates (Figure 3) and SL3S (Figure 4) had differences. The optimum production time for xylanase for B. stearothermophilus SL3A isolates (Figure 4) was at the 48th hour with enzyme activity of $0.1237 \mathrm{mU} / \mathrm{mL}$.

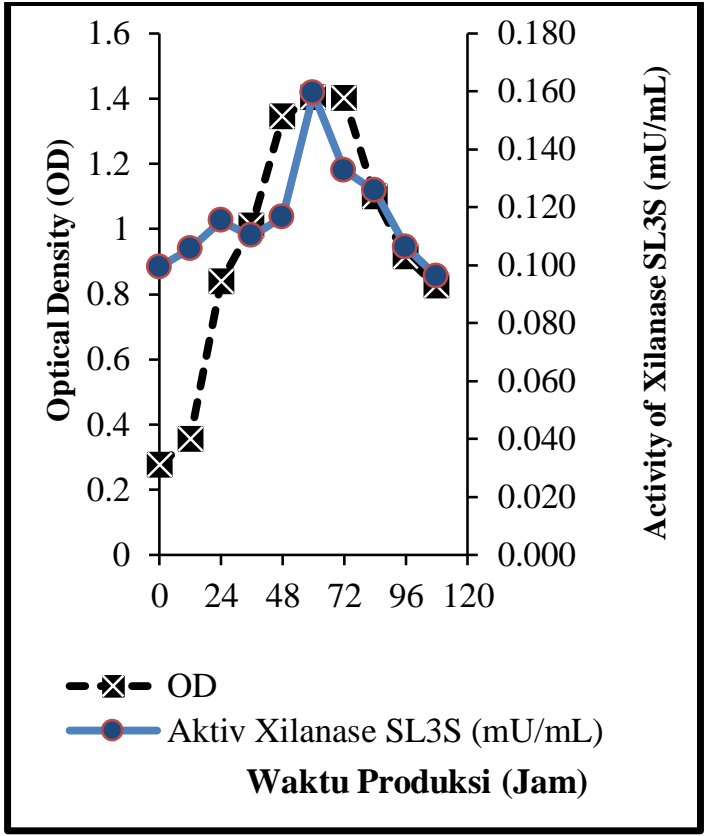

Figure 4. Growth and Xylanase Curve of Bacteria B. stearothermophilus SL3S during Production time at conditions of $40^{\circ} \mathrm{C}$, [corn cob xilan] $0.5 \%$ and speed of 150 rpm

This illustrates the amount of xylan which can be hydrolyzed by xylanase enzyme to xylose. Enzyme activity decreased in the 60th hour. While the optimum production time of xylanase for B. stearothermophilus SL3S isolates (Figure 4) was at the 60th hour with enzyme activity of $0.1593 \mathrm{mU} /$ $\mathrm{mL}$, and in the $72 \mathrm{nd}$ hour the enzyme activity began to decline, due to the reduced ability of bacteria to produce 
enzymes xylanase in hydrolyzing xylan. The condition of cell density and the availability of nutrients in the medium decreases, which is the cause of reduced bacterial ability. The results of the study conducted by Septiningrum and Apriana (2011) produced xylanase enzymes from corn cobs using B. circulans, showing xylanase activity began to form on day 2 with activity of $1.544 \mathrm{U} / \mathrm{mL}$ then increasing sharply until day 4 , then its activity decreased up to day 7 with an activity of 5,102 $\mathrm{U} / \mathrm{mL}$. The highest xylanase activity was obtained on day 4 with an activity of $11.006 \mathrm{U} / \mathrm{mL}$.

\section{Protein Level Measurement}

The results of measurements of protein levels using the Lowry method produce data as shown in Table 4. The measurement results show the highest protein content for SL3A obtained at 48 hours at $9.59 \mathrm{mg} /$ $\mathrm{mL}$. For SL3S it has the highest protein content at 60 hours at $10.07 \mathrm{mg} / \mathrm{mL}$.

Table 4. Measurement Data on Protein Levels of B. stearothermophilus SL3A and SL3S

\begin{tabular}{ccc}
\hline $\begin{array}{c}\text { Fermentation } \\
\text { time }\end{array}$ & $\begin{array}{c}\text { Protein level of SL3A } \\
\text { Isolate (mg/Ml) }\end{array}$ & $\begin{array}{c}\text { Protein level of SL3S } \\
\text { Isolate }(\mathrm{mg} / \mathrm{mL})\end{array}$ \\
\hline 0 & 6.305 & 6.52 \\
\hline 12 & 6.545 & 7.895 \\
\hline 24 & 7.155 & 5.935 \\
\hline 36 & 5.775 & 8.77 \\
\hline 48 & 9.59 & 8.08 \\
\hline 60 & 6.785 & 10.07 \\
\hline 72 & 6.385 & 7.895 \\
\hline 84 & 9.485 & 5.725 \\
\hline 96 & 7.048 & 5.855 \\
\hline 108 & 7.235 & 6.705 \\
\hline
\end{tabular}

According to research conducted by Budiman and Setyawan (2013), dissolved proteins that are measured are not absolute reflecting that all measured enzymes are synthesized by microorganisms, because in the media also contain dissolved proteins in the form of residual media (yeast extract) or the results of microorganism protein metabolism which is secreted.

\section{Characterization of Xylanase Enzymes}

Characterization of xylanase enzymes was carried out by testing the enzyme xylanase extract crude activity

against the effect of temperature, $\mathrm{pH}$, substrate and the effect of metal ions. Characterization was carried out to determine the optimum conditions of crude extract xylanase fermentation process. The enzymes that were characterized were the xylanase enzyme SL3A and SL3S which had the highest activity, namely at the optimum production time of the 48th hour and the 60th hour.

\section{Determination of Optimum Temperature}


Determination of the optimum temperature of SL3A and SL3S bacteria in producing xylanase enzyme was carried out by enzyme incubation with phosphate buffer $\mathrm{pH} 7$ and xylan $1 \%$. Temperatures vary from $35^{\circ} \mathrm{C}$ to $55^{\circ} \mathrm{C}$. The results obtained can be seen in Figure 5. Xylanase activity increases with increasing incubation temperature, but after reaching the maximum temperature the activity decreases. The optimum xylanase temperature of SL3A and SL3S isolates (Figure 5) is $45^{\circ} \mathrm{C}$ with xylanase enzyme activity values of $0.1742 \mathrm{mU} / \mathrm{mL}$ and $0.1962 \mathrm{mU} / \mathrm{mL}$, respectively. Xylanase activity decreases after a temperature of $50^{\circ} \mathrm{C}$. This is because at low temperatures the chemical reaction is slow, while at higher temperatures the reaction takes place faster but the increase in temperature can lead to a process of denaturation and reduce the speed of reaction. The optimum temperature is the temperature that causes a chemical reaction with the greatest speed.

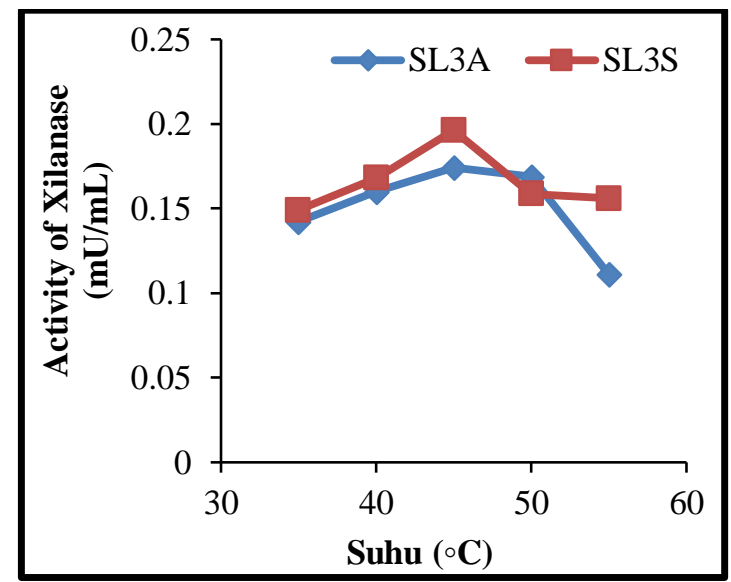

Figure 5. Effect of Temperature on Xylanase Activity of SL3A isolates and SL3S isolates, under conditions of $\mathrm{pH} 7$ and [Xilan] $1 \%$

Research conducted by Susilowati et al. (2012), regarding the xylanase enzyme isolated from Sonai hot springs, Southeast Sulawesi had the highest activity at $\mathrm{pH} 9$ and a temperature of $50^{\circ} \mathrm{C}$ by using rice husk as a substrate. Richana et al. (2008) also succeeded in isolating xylanase-producing bacteria from tapioca waste soil which had the highest activity at pH 9 and a temperature of $50^{\circ} \mathrm{C}$. Richana and Lestina (2003) have conducted research on xylanase enzymes from isolates AIII-5 with sources of xylan from soybean skin having an activity of $35^{\circ} \mathrm{C}$ with a $\mathrm{pH}$ of 9 .

\section{Determination of Optimum pH}

Determination of optimum $\mathrm{pH}$ of SL3A and SL3S bacteria in producing xylanase enzyme was used phosphate-citrate buffer at $\mathrm{pH} \mathrm{5,} \mathrm{6,} 7$ and phosphate buffer for $\mathrm{pH} 8$ at a temperature of $45^{\circ} \mathrm{C}$ which is the optimum temperature obtained from the results of temperature influence characterization. The results of this study can be seen in Figure 6. Data on the effect of $\mathrm{pH}$ on xylanase enzyme activity from $\mathrm{B}$. stearothermophilus SL3A and B. stearothermophilus SL3S, showed that enzyme activity initially increased with increasing $\mathrm{pH}$ values used so that when in phosphate-buffer citrate $\mathrm{pH} 7$ enzyme activity showed the highest value. 


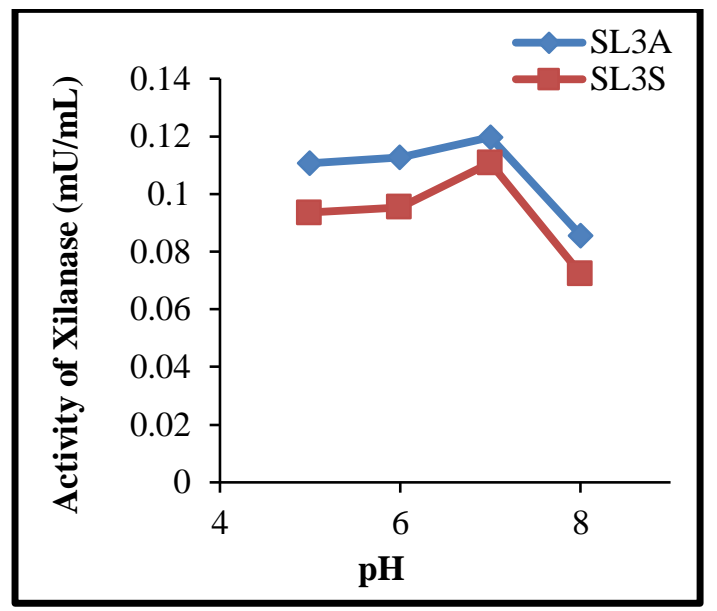

Figure 6. Effect of $\mathrm{pH}$ on Xylanase Enzyme Activity from B. stearothermophilus SL3A and SL3S, at conditions of $45^{\circ} \mathrm{C}$ and [Xilan] $1 \%$

The xylanase enzyme activity (Figure 6) of B. stearothermophilus SL3A was $0.1197 \mathrm{mU} / \mathrm{mL}$ and $0.1108 \mathrm{mU} / \mathrm{mL}$ for B. stearothermophilus SL3S. The enzyme activity began to decrease in phosphate buffer $\mathrm{pH} 8$ with the value of each activity amounting to $0.0858 \mathrm{mU} / \mathrm{mL}$ from B. stearothermophilus SL3A and $0.0724 \mathrm{mU} / \mathrm{mL}$ for B. stearothermophilus SL3S. Based on the data obtained, it can be seen that the optimum $\mathrm{pH}$ of the xylanase enzyme obtained in this study is in the $\mathrm{pH}$ 7 phosphate-citrate buffer. The results of the research conducted by Habibie et al. (2014), the characterization of crude xylanase enzyme from $B$. lichenformis showed optimum at a temperature of $50^{\circ} \mathrm{C}$ with $\mathrm{pH} 7$ using corncob as a substitute for xylan. Palaniswamy et al. (2012), also succeeded in conducting research on xylanase enzyme production using agroindustrial waste as a substrate which has optimum activity at a temperature of $50^{\circ} \mathrm{C}$ with a $\mathrm{pH}$ of 5 .

\section{Determination of Optimum Substrate} Concentration

The results of using xylanase crude extract enzymes in hydrolyzing each substrate used namely pure xylan and corn cob xylan can be seen in Figures 7 and 8 .

Variation of substrate concentration to enzyme activity aims to determine the optimum condition of the substrate that can react with enzymes. Based on the results of the study at a concentration of $1 \%$ the effect of pure xylan substrate concentration on xylanase enzyme activity of B. stearothermophilus SL3A (Figure 7) and B. stearothermophilus SL3S (Figure 8) were $2.636 \mathrm{mU} / \mathrm{mL}$ and $2.345 \mathrm{mU} / \mathrm{mL}$, respectively. At $1 \%$ xylan substrate concentration shows that all active parts are saturated with the substrate so that at this concentration the optimum concentration of xylanase enzyme activity.

The optimum concentration of $2 \%$ corn cob xylan substrate on xylanase enzyme activity of B. stearothermophilus SL3A (Figure 7) and B. stearothermophilus SL3S (Figure 8) were $3.417 \mathrm{mU} / \mathrm{mL}$ and $3.668 \mathrm{mU} / \mathrm{mL}$ respectively. At low substrate concentrations, the active part of the enzyme holds only a small substrate and if the substrate concentration is enlarged, the more substrate can be related to the enzyme 
in the active part. So the greater the substrate concentration, the greater the reaction speed and at a certain concentration limit, all active parts are saturated with the substrate (Poedjadi, 2012).

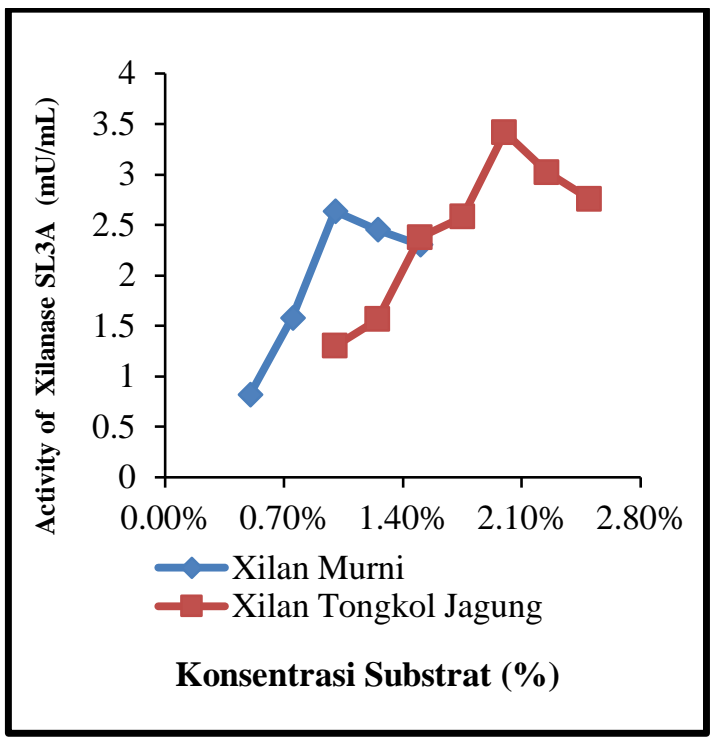

Figure 7. The Influence of Pure Xylan Substrate Concentration and Corn Coban Xilan on Xylanase Enzyme Activity of B. stearothermophilus SL3A, at conditions of $45^{\circ} \mathrm{C}$ and $\mathrm{pH} 7$

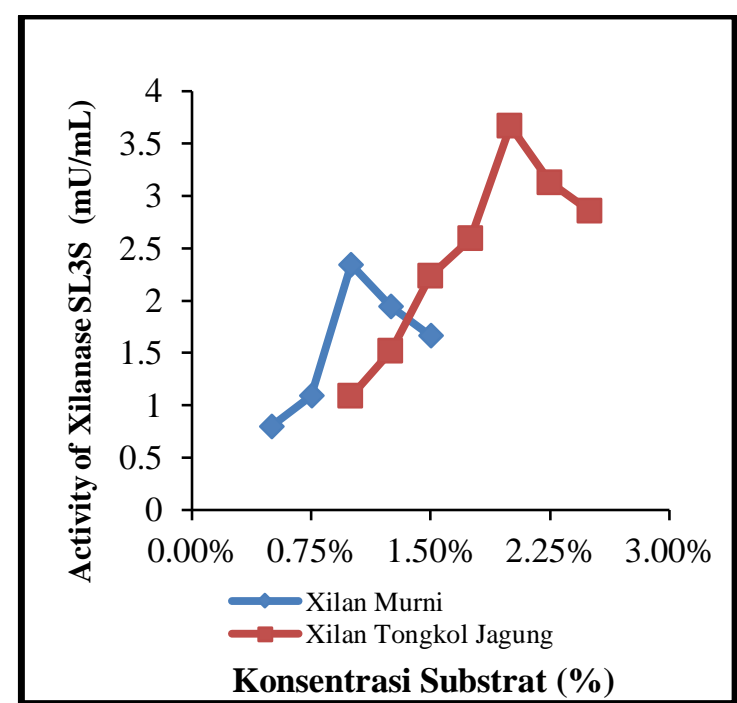

Figure 8. Effect of Pure Xylan Substrate Concentration and Corn $\mathrm{Cob}$ Xylan on Xylanase Enzyme
Activity of B. stearothermophilus SL3S, at conditions of $45^{\circ} \mathrm{C}$ and $\mathrm{pH} 7$

\section{Effect of Addition of Metal Ions}

In this study, to determine the types of metal ions that act as SL3S xylanase enzymes (Table 5) for activators or inhibitors, various types of metal ions such as $\mathrm{CaCl} 2$ are added; $\mathrm{MgCl} 2 ; \mathrm{NiCl} 2$; and $\mathrm{CoCl} 2$ in measuring enzyme activity. There are two different concentrations used for each type of metal ion, namely $1 \mathrm{mM}$ and $5 \mathrm{mM}$. The results obtained can be seen in Tables 5 and 6.

Tabel 5. Effect of Metal Ion Concentration on SL3A Xylanase Enzyme Activity on corn cobs substrate $2 \%$, temperature $45^{\circ} \mathrm{C}$, and $\mathrm{pH} 7$

\begin{tabular}{ccc}
\hline $\begin{array}{c}\text { Metal } \\
\text { Ion }\end{array}$ & \multicolumn{2}{c}{$\%$ Activity of SL3A } \\
\hline & $5 \mathrm{mM}$ & $1 \mathrm{mM}$ \\
\hline $\mathrm{CoCl}_{2}$ & $74,93 \%$ & $45,10 \%$ \\
$\mathrm{CaCl}_{2}$ & $151,70 \%$ & $105,30 \%$ \\
$\mathrm{MgCl}_{2}$ & $115,00 \%$ & $106,30 \%$ \\
$\mathrm{NiCl}_{2}$ & $101,00 \%$ & $101,50 \%$ \\
\hline Control & \multicolumn{3}{c}{$100 \%$} \\
\hline
\end{tabular}

Table 6. Effect of Metal Ion Concentration on SL3S Xylanase Enzyme Activity on corn cobs substrate $2 \%$, temperature $45^{\circ} \mathrm{C}$, and $\mathrm{pH} 7$

\begin{tabular}{ccc}
\hline Logam & \multicolumn{2}{c}{$\%$ Activity of SL3S } \\
\hline & $5 \mathrm{mM}$ & $1 \mathrm{mM}$ \\
\hline $\mathrm{CoCl}_{2}$ & $90 \%$ & $43 \%$ \\
$\mathrm{CaCl}_{2}$ & $145 \%$ & $76 \%$ \\
$\mathrm{MgCl}_{2}$ & $106,60 \%$ & $95 \%$ \\
$\mathrm{NiCl}_{2}$ & $103,10 \%$ & $98 \%$ \\
\hline Control & \multicolumn{3}{c}{$100 \%$} \\
\hline
\end{tabular}


Addition of $\mathrm{CaCl}_{2}$ metal ions; $\mathrm{MgCl}_{2}$; and $\mathrm{NiCl}_{2}$ both at $1 \mathrm{mM}$ and $5 \mathrm{mM}$ concentrations can increase SL3A xylanase enzyme activity (Table 5) and SL3S (Table 6). As an activator, metal ions increase enzymatic reaction activity by acid base catalysis, covalent catalysis, reactant and induction approaches in enzyme or substrate (Prima, 2012). At a concentration of $1 \mathrm{mM}$ for SL3A xylanase enzyme (Table 10) addition of metal ions $\mathrm{CaCl}_{2}, \mathrm{MgCl}_{2}, \mathrm{NiCl}_{2}$ xylanase enzyme activity respectively $105.30 \% ; 106.30 \%$ and $101.50 \%$, while the concentration of 5 $\mathrm{mM}$ was $151.70 \%$ respectively; $115 \%$ and $101 \%$. For a concentration of $1 \mathrm{mM}$ enzyme activity respectively $76 \%$; 95\%; and $97.6 \%$, while the $5 \mathrm{mM}$ concentration of addition of $\mathrm{CaCl}_{2}, \mathrm{MgCl}_{2}, \mathrm{NiCl}_{2}$ xylanase enzyme activity was $145 \%$ respectively; $106.60 \%$; and $103.10 \%$.

Addition of $\mathrm{CoCl}_{2}$ metal ions to SL3A xylanase enzymes (Table 5) and SL3S xylanase enzymes (Table 6) at concentrations of $1 \mathrm{mM}$ and $5 \mathrm{mM}$ decreased enzyme activity so that they were inhibitors. Inhibition of enzyme activity due to the addition of metal ions is suspected because the metal ions affect the active side of the xylanase enzyme so that the three-dimensional structure of the enzyme does not match the substrate. This causes the substrate cannot bind to the active side of the enzyme, so the reaction runs slowly (Prima, 2012).

The results of the research conducted by Richana et al. (2008) showed that the addition of $\mathrm{Fe} 2+$ ions to the xylanase enzyme isolated from B. pumilus RXAIII5 was the highest activator followed by $\mathrm{Cu}^{2+}$ and $\mathrm{Co}^{2+}$, while the addition of $\mathrm{Mg}^{2+}$ ions decreased enzyme activity. Research conducted by Prima (2012), the addition of $\mathrm{Mg}^{2+}$ and $\mathrm{Zn}^{2+}$ ions to xylanase enzyme from Acinetobacter baumanii M-13.2A can increase xylanase activity while the addition of $\mathrm{Fe}^{3+}$ and $\mathrm{Ca}^{2+}$ decreases enzyme activity. This shows that each enzyme has an activator or inhibitor on different metal ions

\section{CONCLUSION}

The conclusions obtained from the results of this study are as follows. Isolate of the thermophilic bacteria producing xylanase enzyme isolated from Makula's hot springs, Tana Toraja is Bacillus stearothermophilus.

The optimum condition of xylanase enzyme using corn cobs waste for SL3A isolates was obtained at 48 hours fermentation time with $0.1237 \mathrm{mU} / \mathrm{mL}$ activity and for SL3S isolates at 60 hours with $0.1593 \mathrm{mU} / \mathrm{mL}$ activity.

The crude extract of xylanase enzyme can hydrolyze xylan from corn cobs at optimum conditions $\mathrm{pH} 7$ and temperature $45^{\circ} \mathrm{C}$, activated by $\mathrm{Ca}^{2+}, \mathrm{Mg}^{2+}$, $\mathrm{Ni}^{2+}$ and inhibited by $\mathrm{Co}^{2+}$ ions.

\section{REFRENCES}

Budiman, A., and Setyawan, S., 2013, Effect of Substrate Concentration, Incubation Length and $\mathrm{Ph}$ in the Process of Isolating Xylanase Enzymes Using Rice Straw Media, Chemical Engineering Department, Faculty of Engineering, Diponegoro University.

Cappucino, J.G., 1983, Microbiology: A Laboratory Manual, Addison Wesley, Publishing Company.

Djide, M.N., and Sartini, 2006, Basic Pharmaceutical Microbiology, Hasanuddin University, Makassar. 
Habibie, F.M., Wardani, A.K., and Nurcholis, M., 2014, Isolation and Identification of Molecular Xylanase-Producing Thermophilic Microorganisms from Lapindo Hot Mud, Food Journal and Agroindustry, 2 (4): 231-238.

Lay, W., 1994, Microbial Analysis in Laboratories, PT. Raja Grafindo Persada, Jakarta.

Nakamura, S., Wakabayashi, K., Nakai, R., Aono, R., and Horikoshi, K., 1993, Purification and Some Properties of Alkaline Xylanase from Alkaliphilic Bacillus sp. Strains 41M-1, Applied and Environmental Microbiology, 59 (7): 2311-2316.

Natsir, H., Patong, A.R., Suhartono, M.T. and Ahmad A., 2010, Production and Characterization of Chitinase Enzymes from Hot Spring in South Sulawesi, Bacillus sp. HSA3-1a, Indo. Journal. of Chem, 10 (2): 256-260.

Natsir, H., Patong, A.R., Suhartono, M.T. and Ahmad, A. 2013. Isolation and Purification of Thermostable Chitinase Bacillus licheniformis Strain HSA3-1a From Sulili Hot Springs in South Sulawesi, Indonesia, Int. Journal of Pharm. Bio Sciences, 4 (3): 1252-1259.

Palaniswamy, M., Arulanandham, TV, and Angayaranni, J., 2012, Production of Xylanase by Litter Degrading Fungal Species Using AgroIndustrial Wastes as Substrates by Solid State Fermentation, Research Journal of Pharmaceutical, Biological and Chemical Sciences, 3 (1 ): 143-149.

Patong, A.R., 2013, Food Chemistry Analysis, Dua Satu Press, Makassar.

Poedjadi, A., 2012, Basics of Biochemistry, UI-Press, Jakarta.

Prayitno, D.A., and Rachmawaty, R., 2011, Use of Enzymes in the Food
Industry, Paper Enzyme Technology, Chemical Engineering FT Diponegoro University, Semarang.

Prima, R.E., 2012, Production and Characterization of Xylanase Coarse Extract from Acinetobacter baumanii M-13.2A, Thesis, published, Faculty of Mathematics and Natural Sciences, Department of Biology, University of Indonesia.

Richana, N., 2002, Production and Prospects of Xylanase Enzymes in Bioindustry Development in Indonesia, Agro Bio Bulletin, 5 (1): 29-36.

Richana, N., and Lestina, P., 2003, Xylanase Production for Bioconversion of Soybean Seed Waste, Center for Biotechnology Research and Agricultural Genetic Resources.

Richana, N., Irawadi T.T, Nur M.A., Syamsu K., and Arkenan, Y., 2007, Xilan Extraction from Corn Cobs, Postharvest Journal, 4 (1): 38-43.

Richana, N., Irawadi T.T, Nur M.A., and Syamsu K., 2008, Isolation of Identification of Xylanase Producing Bacteria and Characterization of Enzymes, Journal of Agro Biogen, 4 (1): 2434.

Septiningrum, K., and Apriana, C., 2011, Xylanase Production from Corn Cob with Bioprocess System Using Bacillus circulans for PreBleaching Pulp, Journal of Industrial Research, 5 (1): 87-97.

Setyawati, I., 2006, Production and Characterization of Microbial Xylanase Isolated from Corn Cobs, Thesis, unpublished, Faculty of Agricultural Technology, Bogor Agricultural University. 
Sopandi, T., and Wardah, 2013, Food Microbiology, Andi Yogyakarta, Yogyakarta.

Susilowati, PE, Raharjo S., Kurniawati D., Rahim R., Sumarlin, and Ardiansyah, 2012, Xylanase Production from Sonai Hot Springs Isolate, Southeast Sulawesi, using Agricultural Waste, Indonesian Naturals Journal, 14 (3): 199- 204.

Thoyib, H., Setyaningsih R., and Suranto, 2007, Selection and Identification of Xylanase-producing Alkaliphilic Bacteria from Bukit Krakitan, Biotechnology, 4 (1): 6-12.

Trismilah and Waltam D.S., 2009, Xylanase Production Using Media for Agriculture and Plantation Waste, Journal of Environmental Technology, 10 (2): 137-144. 